\title{
Knowledge of Rural Woman towards Selected Rural Development Programmes in Bikaner District of Rajasthan
}

\author{
A. Rani*, N. Sareen and D. Dhawan \\ CHSc, SKRAU, Bikaner, Rajasthan, India \\ *Corresponding author
}

\section{A B S T R A C T}

\section{Keywords}

Rural development programme, Knowledge, MGNREGS, NRLM, NRHM

Article Info

Accepted:

22 October 2020 Available Online: 10 November 2020
Rural development is a key factor of Indian Social and Economic growth, as $65.53 \%$ Indians live in rural areas out of which 48.00 per cent are woman. Hence data itself reveal that Rural woman development in India is how much important. There are several rural woman development programmes are running in India, like MGNREGA, NRLM, NRHM, BHAMASHAH (In Rajasthan), PMUY, SABLA, JSY, etc. Here with, we will discuss the knowledge of Rural Woman about MGNREGA, NRLM, NRHM. The study was based on the responses of the respondent collected from Bikaner District of Rajasthan. Four panchyatsamities namely Bikaner, Lunkarnsar, Nokha and shridungargrah was selected for the purpose. Again two gram panchyat from each selected panchyatsamiti were selected randomely i.e Sherea and husansar from Bikaner, Bawanwali and Kaloo from Lunkarnsar, Toliyasar and Seruna from Sri Dugargarh and Mukam and Markhana from Nokha. Two villages from each Gram Panchyat, further form each villages 25 respondent randomly selected for the research. A total number of 400 rural women beneficiaries were selected though random sampling techniques. A self-structured interview schedule was used to collect the information through personal interview to check the knowledge of the respondent about rural development programmes. The data was analysed by using frequency, percentage, Mean, Standard Deviation and Knowledge index as research tools. The finding of the data says that 76.00 per cent of respondent had medium knowledge level, while 21.25 per cent of respondent had low knowledge level and only 02.75 per cent respondent had high knowledge level about MGNREGA. The Mean of the data was 6.53, while Standard Deviation was 1.17. Again 89.25 per cent of respondent had medium knowledge level of NRLM scheme, while 10.50 per cent of respondent had low knowledge level of NRLM and only 00.25 per cent respondent had high knowledge level of NRLM scheme. The Mean of the data was 7.54, while Standard Deviation was 0.86. And 93.25 per cent of respondent had medium knowledge level of NRHM, while 03.50 per cent of respondent have high knowledge level of NRHM and only 03.25 per cent respondent had low knowledge level of NRHM. The Mean of the data was 6.39, while Standard Deviation was 1.12 .

\section{Introduction}

Rural development has attracted global attention, especially in developing country like India, where majority of people still lives in rural areas. Rural development is directly proportional to employment ratio, Education system, gender equality, infrastructure 
development, etc in rural areas. Hence, the Government of India is mainly focusing on these fundamental needs of the rural masses.

The Government of India and Rajasthan have launched so many rural development programmes for socio economic upliftment of the rural people, like - Integrated Rural Development Programme(IRDP), Mahatma Gandhi National Rural Employment Act Programme (MGNREGA), National Rural Livelihood Mission (NRLM), National Rural Health Mission (NRHM), Pradhan Mantri was Yojana (PMAY), BHAMASHAH, Pradhan Mantri Ujjwala Yojana (PMUY), Deen Dayal Upadhyay Grameen Kaushal Yojana (DDUGKY), Roshni: Skill Development Scheme for Tribals, Sansad Adarsh Gram Yojana, Pradhan Mantri Gram Sadak Yojna (PMGSY), Training to Rural Youth for Self Employment (TRYSEM), Antyodaya Anna Yojna (AAY), Village Grain Bank Scheme, Aam Aadmi BimaYojna, KutirJyoti Programme, etc.

Out of the above mentioned various rural development programmes, in many programmes women are the centre of the scheme. Following schemes taken into account in this thesis to find out the knowledge of the beneficiaries - Mahatma Gandhi National Rural Employment Act Programme (MGNREGA), National Rural Livelihood Mission (NRLM), National Rural Health Mission (NRHM).

\section{Materials and Methods}

\section{Locale and sampling}

\section{Locale of study}

The study was conducted in Bikaner district of Rajasthan. The area was well known to the researcher and was easily accessible.

\section{Selection of panchyatsamities}

There are seven panchyatsamites in Bikaner district namely- Bikaner, Kolayat, Khajuwala, Loonkarensar, Nokha, ShriDungargarh and panchu. Out of them four panchyatsamities namely Bikaner, Lunkarnsar, Nokha and shridungargrah was selected according to convenience of researcher.

\section{Selection of gram panchyat}

There are 41 gram panchyat in Bikaner panchayat samiti, 30 in Lunkaransar,36 in Nokha and 41 in Sri Dugargarh. Two gram panchyat from each selected panchyatsamiti was selected randomly i.e Sherea and husansar from Bikaner, Bawanwali and Kaloo from Lunkarnsar, Toliyasar and Seruna from Sri Dugargarh and Mukam and Markhana from Nokha.

\section{Selection of village:}

Two villages from each gram panchyat were selected randomly.

\section{Selection of respondents}

From each village 25 rural women were selected randomly thus forming the sample size of 400 respondents.

\section{Tools for data collection}

The data was analysed by using frequency, percentage, Mean, Standard Deviation and Knowledge index as research tools.

Knowledge was operationally defined as those behaviour and test situations which emphasized the remembering either by reorganization or by the recall of ideas and material on some phenomenon (Bloom et al., 1955).

To measure the knowledge of farmers about 
the rural development programmes 30 statements were used. The questions framed were objective type i.e., yes or no statements with given score of one for correct response and non for incorrect response. The total knowledge scores for each respondent was calculated by summing up the number of items correctly answered by an individual respondents and the maximum score one could obtained was 30 and minimum score was zero. By adding the scores of all the items, the individual total scores was work out. The beneficiaries were categorized into three groups based on the mean and standard deviation.

\begin{tabular}{|l|l|l|}
\hline S.No. & Category & Scores \\
\hline $\mathbf{1 .}$ & Low level of knowledge & $\begin{array}{l}\text { Mean-S.D and } \\
\text { below }\end{array}$ \\
\hline 2. & Medium level of knowledge & Mean \pm S.D \\
\hline 3. & High level of knowledge & $\begin{array}{l}\text { Mean +S.D } \\
\text { and above }\end{array}$ \\
\hline
\end{tabular}

\section{Collection of data}

The data were collected by personnel interview techniques. Keeping in mind the purpose of study, the personnel interview technique was preferred over others because of its several added advantages. Interview provides a situation where face to face discussion can take place and the interviewer finds an opportunity to motivate the respondents to react and establish rapport with the respondents who in turn can feel free to give answers. The attention was given to the convenience of the respondents regarding clear understanding of the question.

\section{Results and Discussion}

\section{Knowledge of rural women regarding selected rural development programmes}

Success of a work depends upon the knowledge of the worker, who is executing that work. Hence it is crystal clear that success or implementation of any rural development programme very much depends upon the knowledge of the programme among the beneficiaries. Keeping this in mind some different MCQs for different selected rural development programmes were presented to respondent for their valuable response with utmost sincerity. Based on their response, frequency and percentage were calculated for each MCQ. The data of the same presented here below in knowledge table from table 1 . to table 6 .

Table 1.shows the knowledge of rural woman about MGNREGS. According to the data 100.00 per cent rural woman knew that there is no discrimination of wages between men and women, 92.00 per cent rural woman had knowledge that Employment should be provided within radius of $5 \mathrm{kms}, 91.00$ per cent respondent had knowledge that MGNREGS provides 100 days of employment, equal per cent of respondent $(85.00 \%)$ had knowledge that only adult members been given work under MGNREGS and the employment has to be provided within 15 days from the submission of application, 78.80 per cent had knowledge that The panchyat/program officer is the person to whom the application to be submitted, equal per cent of respondent had knowledge that MGNREGS scheme is funded by Central Government and procedure to get a job card, only 16.50 per cent of respondent had knowledge that MGNREGS provides legal guarantee of employment and only 5.00 per cent of respondent had knowledge that Social auditing is an integral part of MGNREGS.

Thus the overall knowledge index of rural woman about MGNREGS was 65.32 per cent, which shows that 65.32 per cent of rural woman had knowledge about MGNREGA Scheme, which is more than half of the respondent. The findings are similar with findings of Kenchanagoudra et al., (2007) and 
Mishra (2007)

As per the data shown in table 2, 76.00 per cent of respondent had medium knowledge level, while 21.25 per cent of respondent had low knowledge level and only 02.75 per cent respondent had high knowledge level. The Mean of the data is 6.53, while Standard Deviation is 1.17 .

Table 3 shows the knowledge of rural woman about NRLM scheme. As per the data collected from the respondents, equal per cent $(100.00 \%)$ of respondents had knowledge that NRLM is enabling the poor to access gainful skilled self-employment and An SHG is a financial intermediary committee of 10 to 20 local rural women and men, 95.00 per cent of respondent had knowledge that The basic idea behind this programme is to organize the poor into self-help group, Equal per cent (93.00\%) of respondent had knowledge that The prime purpose of SHG is to encouraging saving habit among the members and NRLM provides revolving fund(RF) of Rs.10,000/- to Rs.15,000/- to SHG, 91.00 per cent of respondent had knowledge that SHG members use saving for internal lending to meet their emergent credit need. 88.80 per cent of respondent had knowledge that NRLM is panacea for rural youth to come out of poverty, 78.00 per cent of respondent had knowledge that Panchsutra of SHG is regular meeting, saving, internal lending, repayment and book keeping, only 22.50 per cent of respondent had knowledge that There is a cluster level forum to share the experience of SHG, and only 4.50 per cent of respondent had knowledge that NRLM scheme was launched in June 2011. While no respondent had knowledge that NRLM is a poverty alleviation project implemented by Ministry of Rural Development Programme and NRLM is remodelled from SGSY.

Table.1 Distribution of respondents according to their knowledge regarding MGNREGS $(n=400)$

\begin{tabular}{|c|c|c|c|c|c|c|}
\hline \multirow[t]{2}{*}{ S.No } & \multirow[t]{2}{*}{ Statement } & \multicolumn{2}{|c|}{ Yes } & \multicolumn{2}{|c|}{ No } & \multirow[t]{2}{*}{ Knowledge Index } \\
\hline & & $\mathbf{F}$ & $\%$ & $\mathbf{F}$ & $\%$ & \\
\hline 1 & $\begin{array}{l}\text { MGNREGA Provides legal guarantee of } \\
\text { employment. }\end{array}$ & 66 & 16.5 & 334 & 83.5 & 16.50 \\
\hline 2 & It provides 100 days of employment. & 364 & 91 & 36 & 9 & 91.00 \\
\hline 3 & Only adult member been given work. & 340 & 85 & 60 & 15 & 85.00 \\
\hline 4 & $\begin{array}{l}\text { MGNREGA scheme is funded by central } \\
\text { government. }\end{array}$ & 200 & 50.0 & 200 & 50.0 & 50.00 \\
\hline 5 & $\begin{array}{l}\text { The employment has to be provided within } 15 \\
\text { days from the submission of application. }\end{array}$ & 340 & 85 & 60 & 15 & 85.00 \\
\hline 6 & Do you know the procedure to get a job card? & 200 & 50.0 & 200 & 50.0 & 50.00 \\
\hline 7 & $\begin{array}{l}\text { The panchyat/program officer is the person to } \\
\text { whom the application to be submitted. }\end{array}$ & 315 & 78.8 & 85 & 21.3 & 78.75 \\
\hline 8 & $\begin{array}{l}\text { Employment should be provided within radius of } \\
5 \mathrm{~km} \text {. }\end{array}$ & 368 & 92 & 32 & 8 & 92.00 \\
\hline 9 & $\begin{array}{l}\text { There is no discrimination of wages between men } \\
\text { and women. }\end{array}$ & 400 & 100 & 0 & 0 & 100.00 \\
\hline 10 & Social auditing is an integral part of MGNREGA. & 20 & 5 & 380 & 95 & 05.00 \\
\hline & Overall Knowledge Index & & & & & 65.32 \\
\hline
\end{tabular}


Table.2 Distribution of respondents according to their overall all knowledge about MGNREGS: $(n=400)$

\begin{tabular}{|l|l|l|l|}
\hline S.No. & Categories & Frequency & Per centage \\
\hline 1. & Low (below 6) & 85 & 21.25 \\
\hline 2. & Medium (6 to 8) & 304 & 76.00 \\
\hline 3. & High (above 8) & 11 & 02.75 \\
\hline & MEAN $-\mathbf{6 . 5 3}$ & & S D $-\mathbf{1 . 1 7}$ \\
\hline
\end{tabular}

Table.3 Distribution of respondents according to their knowledge regarding (NRLM): $(n=400)$

\begin{tabular}{|c|c|c|c|c|c|c|}
\hline \multirow[t]{2}{*}{ S.NO. } & \multirow[t]{2}{*}{ Statement } & YES & & NO & & \multirow{2}{*}{$\begin{array}{l}\text { Knowledge } \\
\text { Index }\end{array}$} \\
\hline & & $\mathbf{F}$ & $\%$ & $\mathbf{F}$ & $\%$ & \\
\hline 1 & NRLM Scheme was launched in June 2011. & 18 & 4.5 & 382 & 95.5 & 04.50 \\
\hline 2 & $\begin{array}{l}\text { NRLM is a poverty alleviation project } \\
\text { implemented by Ministry of Rural Development } \\
\text { Programme. }\end{array}$ & - & - & 400 & 100 & 00.00 \\
\hline 3 & $\begin{array}{l}\text { The basic idea behind this Programme is to } \\
\text { organize the poor into Self-help group. }\end{array}$ & 380 & 95 & 20 & 5 & 95.00 \\
\hline 4 & NRLM is remodeled from SGSY. & - & - & 400 & 100 & 00.00 \\
\hline 5 & $\begin{array}{l}\text { NRLM is enabling the poor to access gainful } \\
\text { skilled self-employment. }\end{array}$ & 400 & 100 & - & - & 100.00 \\
\hline 6 & $\begin{array}{l}\text { NRLM is Panacea for rural youth to come out of } \\
\text { poverty. }\end{array}$ & 355 & 88.8 & 45 & 11.3 & 88.75 \\
\hline 7 & $\begin{array}{l}\text { An SHG is a financial intermediary committee of } \\
10 \text { to } 20 \text { local women and men. }\end{array}$ & 400 & 100 & - & - & 100.00 \\
\hline 8 & $\begin{array}{l}\text { The prime purpose of SHG is to encouraging } \\
\text { saving habit among the members. }\end{array}$ & 372 & 93 & 28 & 7 & 93.00 \\
\hline 9 & $\begin{array}{l}\text { SHG members use saving for internal lending to } \\
\text { meet their emergent credit need. }\end{array}$ & 364 & 91 & 36 & 9 & 91.00 \\
\hline 10 & $\begin{array}{l}\text { NRLM provides revolving fund (RF) of Rs. } \\
10000 \text { to } 15000 \text { to SHG. }\end{array}$ & 327 & 93 & 73 & 18.3 & 81.75 \\
\hline 11 & $\begin{array}{l}\text { There is a cluster Level Forum to share the } \\
\text { experience of SHG. }\end{array}$ & 90 & 22.5 & 310 & 77.5 & 22.50 \\
\hline 12 & $\begin{array}{l}\text { Panchsutra of SHG is regular meeting, saving, } \\
\text { internal lending, repayment and book keeping. }\end{array}$ & 321 & 78 & 88 & 22 & 80.25 \\
\hline & Overall Knowledge Index & & & & & 63.06 \\
\hline
\end{tabular}

Table.4 Distribution of respondents according to their overall knowledge regarding (NRLM): $(n=400)$

\begin{tabular}{|l|l|c|c|}
\hline S.No. & Categories & Frequency & Per centage \\
\hline 1. & Low (below 7) & 42 & 10.50 \\
\hline 2. & Medium (7 to 9) & 357 & 89.25 \\
\hline 3. & High (above 9) & 01 & 00.25 \\
\hline & MEAN - 7.54 & & S D $-\mathbf{0 . 8 6}$ \\
\hline
\end{tabular}


Table.5 Distribution of respondents according to their knowledge regarding (NRHM): $(n=400)$

\begin{tabular}{|c|c|c|c|c|c|c|}
\hline \multirow[t]{2}{*}{ S.NO. } & \multirow[t]{2}{*}{ Statement } & Yes & & No & & \multirow{2}{*}{$\begin{array}{l}\text { Knowledge } \\
\text { Index }\end{array}$} \\
\hline & & $\mathbf{F}$ & $\%$ & $\mathbf{F}$ & $\%$ & \\
\hline 1 & $\begin{array}{l}\text { JSY under NRHM scheme was launched on } 12^{\text {th }} \text { april } \\
2005 \text {. }\end{array}$ & 15 & 3.75 & 385 & 96.3 & 03.75 \\
\hline 2 & NRHM is a Government sponsored programme. & 56 & 14 & 344 & 86 & 14.00 \\
\hline 3 & $\begin{array}{l}\text { JSY scheme focused on institutional delivery among } \\
\text { the poor family. }\end{array}$ & 377 & 94.3 & 23 & 5.75 & 94.25 \\
\hline 4 & ASHA workers role is very important in this scheme. & 400 & 100 & - & - & 100.00 \\
\hline 5 & $\begin{array}{l}\text { The scheme provides at least } 3 \text { antenatal cares and } \\
\text { post-delivery visit. }\end{array}$ & 320 & 80 & 80 & 20 & 80.00 \\
\hline 6 & $\begin{array}{l}\text { Cash assistance in rural area for mother is Rs.700/- } \\
\text { and 600/-for urban area. }\end{array}$ & 400 & 100 & - & - & 100.00 \\
\hline 7 & $\begin{array}{l}\text { JSY disbursing authority will keep imprest money of } \\
\text { Rs. 5,000/-with every ANM. }\end{array}$ & 148 & 37 & 252 & 63 & 37.00 \\
\hline 8 & $\begin{array}{l}\text { ANM will keep advance cash of at least Rs. 1500/- } \\
\text { with ASHA worker for any emergency. }\end{array}$ & 162 & 40.5 & 238 & 59.5 & 40.50 \\
\hline 9 & $\begin{array}{l}\text { State health mission chaired by the Chief Minister of } \\
\text { the State. }\end{array}$ & 122 & 30.5 & 278 & 69.5 & 30.50 \\
\hline 10 & $\begin{array}{l}\text { NRHM provides } 30-50 \text { bedded CHC per lakh of } \\
\text { population. }\end{array}$ & 155 & 38.8 & 245 & 61.3 & 38.75 \\
\hline 11 & Every village have at least one ASHA. & 400 & 100 & - & - & 100.00 \\
\hline & Overall Knowledge Index & & & & & 58.06 \\
\hline
\end{tabular}

Table.6 Distribution of respondents according to their overall knowledge regarding (NRHM) $(n=400)$

\begin{tabular}{|l|l|c|c|}
\hline S.No. & Categories & Frequency & Per centage \\
\hline 1. & Low (below 5) & 13 & 03.25 \\
\hline 2. & Medium (5 to 8) & 373 & 93.25 \\
\hline 3. & High (above 8) & 14 & 03.50 \\
\hline & MEAN - 6.39 & & S D - 1.12 \\
\hline
\end{tabular}

Thus the overall knowledge index of rural woman about NRLM was 63.06 per cent, which shows that 63.06 per cent of rural woman had knowledge about NRLM Scheme, which is more than half of the respondent. The findings are similar with findings of Garg et al., (2012).

As per the data shown in table 4, 89.25 per cent of respondent had medium knowledge level of NRLM scheme, while 10.50 per cent of respondent had low knowledge level of NRLM and only 00.25 per cent respondent had high knowledge level of NRLM scheme. The Mean of the data is 7.54 , while Standard Deviation is 0.86 .

Table 5 provides the information about the knowledge of rural woman about NRHM scheme. As per the response collected from the respondents, equal per cent $(100.00 \%)$ of respondents had knowledge that ASHA workers role is very important in JSY scheme, Cash assistance in rural area for mother is Rs.700/- and Rs.600/- for urban areas and Every village have at least one ASHA worker, 
again 94.30 per cent respondent had knowledge that JSYT scheme focused on institutional delivery among the poor family, followed by 80.00 per cent of respondent had knowledge that JSY scheme provides at least 3 antenatal cares and post-delivery visit, again 40.50 per cent of respondents knew that ANM will keep advance cash of at least Rs.1500/with ASHA worker for any emergency, 38.80 per cent of respondent had knowledge that NRHM provides 30-50 bedded CHC per lakh of population, 37.00 per cent of respondent had knowledge that JSY disbursing authority will keep imprest money of Rs.5,000/- with every ANM, 30.50 per cent of respondent knew that State health mission chaired by the Chief Minister of the State, and only 14.00 and 3.75 per cent of respondent had knowledge that NRHM is a Government sponsored programme and JSY under NRHM scheme was launched on $12^{\text {th }}$ April 2005 respectively.

Thus the overall knowledge index of rural woman about NRHM was 58.06 per cent, which shows that 58.06 per cent of rural woman had knowledge about NRHM Scheme, which is more than half of the respondent. The findings are similar with findings of Pujar et al., (2017), Patel et al., (2016) and Narwal et al., (2016).

As per the data shown in table 6, 93.25 per cent of respondent had medium knowledge level of NRHM, while 03.50 per cent of respondent had high knowledge level of NRHM and only 03.25 per cent respondent had low knowledge level of NRHM. The Mean of the data is 6.39 , while Standard Deviation is 1.12 .

From the above findings it can be concluded that -

Majority of the respondents had medium level of overall knowledge, however they possess very good knowledge of MGNREGS, NRLM, BHAMASHAH scheme.

The overall attitude of the respondents is at medium level, however they carries positive attitude towards MGNREGS, NRHM, NRLM and BHAMASHAH scheme.

There are some drawback in implementing these scheme, which gives constraint to the respondent. Like - irregularity in monetary discipline, difference in principle and practice of the scheme, poor grievance red ressal system, economic development of respondent is missing, while this is a very important aim of all these scheme

\section{References}

Blooom, B.S., Englehardt, M., Frust, G., Hill, $\mathrm{W}$ and Krathwhol, D. R. 1955. Taxonomy of Education Objectives: The cognitive domain. New York, Longmans Green

Mishra, B.P., Mishra, B., Singh, B., Yadav, R.R. and Kiran (2007). Relationship between Different Variables and factor causing failure of Youth clubs. Indian research journal of extension education vol. 7p.p. 62-64.

Kenchanagoudra, S.M. (2007). An analytical study on Sampoornagrameen Rozagar Yojana (SGRY) in Gadag district of Karnataka State. M.Sc.(Ag) Thesis submitted to the University of Agricultural Sciences, Dharwad.

Narwal, A., Bhardwaj, G.,Devi, S. (2016). A descriptive study to assess the knowledge among the antenatal mothers regarding Janani Suraksha Yojana in a selected hospital of Bhopal, Madhya Pradesh. Asian Journal of Nursing Education and Research, 6(3):377-380.

Patel, B.B., Gurmeet, P., sinalkar, D.R., Kapil, H., Pandya, A.M.,Singh, 
N.,(2016). Knowledge about antenatal care among pregnant women. Medical Journal of Dr. D. Y. Patil University, 9(3): 354-362.

Pujar, L., Chanda, K. and Morab, A. (2017).Knowledge on reproductive health of rural farm women. International Journal of Home science,3(1),229-233.
Garg, S.K., Badodiya, S.K., Dalpuria, O.P. and Rawat, U. 2012. Impact of Swarnajayanti Gram Swarozgar Yojana on Poverty Alleviation in Morar Block of Gwalior District. Indian Research Journal of Extension Education. 1:189-191.

\section{How to cite this article:}

Rani, A., N. Sareen and Dhawan, D. 2020. Knowledge of Rural Woman towards Selected Rural Development Programmes in Bikaner District of Rajasthan. Int.J.Curr.Microbiol.App.Sci. 9(11): 3313-3320. doi: https://doi.org/10.20546/ijcmas.2020.911.396 